
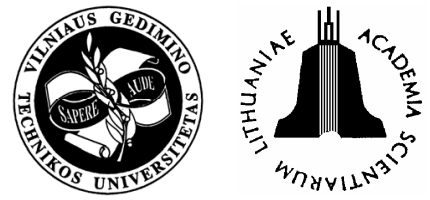

\title{
MODIFIED ASPHALT MIXTURES RESISTANCE TO PERMANENT DEFORMATIONS
}

\author{
Piotr Radziszewski \\ Bialystok Technical University, Wiejska Street 45A, 15-351 Bialystok, Poland \\ E-mail: prorektor.promocja@pb.edu.pl \\ Received 27 April 2007; accepted 03 Oct 2007
}

\begin{abstract}
Permanent deformations, primarily in the form of ruts, are one of the basic asphalt pavement damages impairing its service properties. Application of appropriate asphalt mixtures and binder modification are effective methods for improving asphalt courses resistance. While being manufactured, stored, fitted into a road pavement and during long term service, bitumen binders and asphalt mixtures are subject to continuous unfavourable ageing processes during which pavement courses characteristics change considerably, resistance to permanent deformations being among them. This article presents rut and dynamic creep test results of concrete, SMA (stone mastic asphalt), MNU (thin courses of noncontinuous grain mixtures), Superpave mixture and porous asphalt mixture of two air void content percentages: $15 \%$, $20 \%$. Asphalt concrete mixtures, MNU's and porous asphalt mixtures contained elastomer, plastomer and fine rubber modified binders. Samples for laboratory rut tests were made by slab compaction because this method, as the author's previous research had shown, was the closest to 'in-situ' conditions. Resistance to permanent deformations of the examined specimens was evaluated before aging, after technological aging (short term ageing) and after service ageing (longterm ageing). The test results show that resistance to permanent deformations depends on the kind of asphalt mixture and binder applied. Concrete asphalts with fine rubber modified bitumens and concrete asphalts with $7 \%$ polymer modified binders as well as SMA's and Superpave mixtures with unmodified binders appeared to be most resistant to permanent deformations after a long-term laboratory ageing. It was proved that the overall evaluation of resistance to permanent deformations could be obtained by rut and creep testing of asphalt mixtures exposed to short- and long-term ageing. Simultaneous determining 4 parameters: maximum rut depth after short-term ageing, rutting coefficient after operational ageing, stiffness creeping modulus after long-term ageing and cumulated deformation after short-term ageing, facilitates full characteristics of modified asphalt mixes designed to be built in the wearing course of a road pavement.
\end{abstract}

Keywords: modified asphalt mixture, compaction, ageing, permanent deformation, rut, creep.

\section{Introduction}

Vehicle wheels load acting on the pavement of a road may result in permanent deformation in the form of imprints, tracks, corrugations, shovings and ruts. The deformations considerably impair road service properties. Ruts are most dangerous because they might cause vehicles to skid during precipitation. Rut forming is connected with the process of accumulation of deformations of asphalt courses of the pavement resulting from frequent dynamic loads. What occurs then is 'pushing' asphalt courses in wheel tracks [1-4].

Susceptibility to rutting depends on numerous factors. According to SHRP (Strategic Highway Research Program) bitumen binder ( stiffness modulus, contents) is approx a $50 \%$ influence on the rut size [5]. An increase in binder viscosity through the use of modified bitumens results in a decrease in asphalt mixture susceptibility to rutting. The susceptibility also largely depends on the asphalt mixture structure. A mixture in which the grains are in contact and form a contact structure is most resistant. A mineral mixture should consist of hard cubic grained aggregate containing either a limited amount of natural sand or broken sand solely $[3,6]$.
Recently, due to the ever-increasing heavy loading to Poland roads and in order to avoid excessive pavement rutting, new technologies have been introduced. SMA's are commonly applied for wearing courses, and thin courses of non-continuous grain mixtures placed on stiff thick binding courses are ever so often built in [3, 7]. Binding courses and base courses are mainly built from coarse-grained mixtures of the asphalt concrete type. In many countries mixtures containing a lot of air voids called porous asphalt mixtures are used [8, 9]. In the USA, however, Superpave mixtures are becoming more and more popular [10]. To produce them both modified and unmodified binders are used. In the future some of the mixtures will probably be used in Poland for road pavement.

As domestic and overseas experience shows, asphalt binder modification is an effective method for improving asphalt mixture properties [11-14]. In practice SBS (styren butadien styren) elastomer and EVA (ethyl-vinyl accetate) plastomer are most often used. For ecological reasons fine rubber from scrap vehicle tyres should be used for binder modifying $[11,14]$. 
While being manufactured, stored, fitted into a road pavement and during long-term operational use, bitumen binders and asphalt mixtures are subject to continuous unfavourable ageing processes [15-19]. During the processes elastic viscosity of materials changes considerably, which results in a decrease of road pavement durability, its resistance to permanent deformations including.

This article presents rutting and dynamic creep test results of the following asphalt mixtures: asphalt concrete (of 0/12.8 mm graining), SMA (of 0/12.8 mm graining), MNU (of 0/12.8 mm graining), Superpave mixture (of $0 / 12.5 \mathrm{~mm}$ graining) and porous asphalt mixture of two percentages of air void content: $15 \%$ and $20 \%$ (of $0 / 11 \mathrm{~mm}$ graining). Resistance to permanent deformations of the mixtures was evaluated before ageing, after technological ageing (short-term ageing) and service ageing (long-term ageing).

\section{Materials and methods}

Laboratory tests were conducted on asphalt concretes designed for wearing courses of road pavements (traffic load of KR3 - KR6 category). They contained SBS elastomer modified binders (of 3\%, $5 \%, 7 \%$ additive to bitumen $50 / 70$ penetration), EVA plastomer modified binders (of $3 \%, 5 \%, 7 \%$ additive to bitumen 50/70 penetration), rubberised bitumen binders (of $17 \%, 19 \%$, $21 \%$ additive to bitumen 50/70 penetration) and unmodified binders $35 / 50$ and 50/70 penetrations. Other asphalt mixtures tested and designed for wearing surfaces were: SMA with $35 / 50$ bitumen, MNU with rubberised bitumen binder (of $17 \%$ additive to bitumen 50/70) and Modbit 30B binder (elastomer modified binder), Superpave mixture with $35 / 50$ bitumen and porous asphalt mixture with SBS Modbit 80C binder. Additionally, tests in compaction processes included asphalt concretes produced in a mixture plant: asphalt concrete of $0 / 12.8$ graining for wearing course with $30 / 50$ bitumen and asphalt concrete of $0 / 16 \mathrm{~mm}$ graining for binding courses with $50 / 70$ bitumen.

The composition of the asphalt mixtures was developed according to standards and recommendations [3]. The mixtures were laboratory made in an automatic mixing device which guaranteed obtaining a homogenously coated mixture.

\subsection{Compaction of asphalt mixtures in a laboratory}

The way the laboratory samples are obtained should reflect the conditions 'in situ'. This especially applies to the compaction, being the result of changes in the orientation of aggregates grains, the changes in the contact of the grains and the size of the contact area between the aggregate and bitumen and also the result of changes in the thickness of bituminous envelope in the area of contact between the aggregate grains $[20,21]$. The compaction of asphalt concrete directly affects its strength and service life.

In order to make it possible to compare various parameters characterising asphalt concrete built in the road surface as well as the ones prepared in laboratories, these samples ought to undergo identical compaction.

At present, the following methods of laboratory asphalt concrete compaction are applied: static compaction, impact compaction, kneading compaction, gyratory-shear compaction and rolling-wheel compaction.

The article analyses two methods of laboratory compaction, namely, compaction in accordance with Marshal's method and rolling-wheel compaction. While selecting the methods, the author considered the fact that compaction with Marshall's hammer is widely used in Poland. Besides, the author made use of the results of SHRP (Strategic Highway Research Program) [20] suggesting the application of gyratory-shear or rolling-wheel method and as the one being the closest to 'in situ' conditions. The methods of kneading and gyratory-shear compaction are discussed [7, 20, 21].

In this research, plant produced asphalt mixtures were used. The mixtures had been planned to be used in the road surface designated for heavy traffic. The composition of bituminous mixtures for the base and wearing courses are typical and meet the Polish standard. In accordance with the research schedule, samples have been collected from asphalt mixtures in the concrete-mixing plant. The mixtures have been marked in the following way:

- DR-D - samples collected from the base course of the road surface;

- DR-DP - samples drilled out of plates produced in the laboratory from the asphalt mixture prepared in the concrete-mixing plant to be used in the base course;

- DR-DM - samples prepared in accordance with Marshall's method from asphalt mixture produced in the concrete-mixing plant, to be used in the base course;

- DR-G - samples drilled out of the wearing course;

- DR-GP - samples drilled out of the plates produced in the laboratory from asphalt mixture prepared in the concrete-mixing plant, to be used in the wearing course;

- DR-GM - samples prepared in accordance with Marshall's method from asphalt mixture produced in the concrete mixing plant to be used for the wearing course.

The samples have been drilled out in the places where asphalt mixture was unloaded from the same lorry, from which the material for laboratory compaction had been collected.

Impact compaction has been carried out according to the standard use of Marshall's hammer.

In rolling-wheel compaction a special equipment was used. It consisted of a steel form for plate samples $60 \times 60 \mathrm{~cm}$, a hammer for initial vibrating compaction, a heated up steel roller for static compaction. The steel roller $(165 \mathrm{~kg})$ of $50 \mathrm{~cm}$ diameter was adjusted to the form with the width of the compactor $(60 \mathrm{~cm})$. The compaction was carried out in 2 stages. After putting the heated up mixture into the form (precautions had been taken to avoid the mixture's segregation) the mixture was 
compacted with a vibrating plate for $1 \mathrm{~min}$. The second stage of compaction consisted of rolling along and across the compacted plate with a manual steel roller. The rolling took approx 2 min. Cylindrical samples were drilled out of the plates at different distances from the plates edges. The plates were also cross-cut along and across in order to analyse the homogeneity of mixture's compactness. The samples prepared in the laboratory and drilled out of the road surface were subject to the following tests:

- stability, flow and stiffness index according to Marshall's method,

- resistance to tension according to Brazilian method (tensile strength),

- creep resistance according to dynamic pressing method.

The structure of cross-cut samples was analysed on the basis of visual testing and microscopic observation. The results of mechanical tests were subject to principal components analysis [22].

\section{The research of the asphalt mixtures structure}

Asphalt concrete after compacting may form a nonoriented or oriented structure. The first type of structure is formed by a well-compacted material, stiff and very elastic. In contrast, the non-oriented structure is characterised by a smaller degree of compactness and stiffness.

The most significant and distinct criterion of the compactness of an asphalt mixture is the amount of air voids. This amount depends on the type of the aggregate, the content of binder and the compaction method. Asphalt concrete requires a small content of air voids, but above the defined minimum value level. The differences in the air voids volume in the same series of samples did not exceed $0.5 \%$. Hence, one cannot claim that the different characteristics of investigated samples are, as a result, of varied degrees of their compactness. The reasons of diversified behaviour of the same asphalt mixture compacted by different methods should be looked for elsewhere.

After mixing the grains of the aggregate are encased in a mastic membrane. During compacting the thickness of the membrane is reduced while the structure becomes more oriented. Compacting with the impact method, which was observed on the samples' intersections, does not result in a significant shift in the aggregate orientation. The lower surface of the sample is, however, rougher, coarse grains are visible, divided by large pores. The top surface, being in contact with the compacting machine, is smoother and made up of mainly fine aggregate. The smooth side surfaces of the samples compacted in steel forms are shaped by mastics and finer fractions of aggregate. Bigger grains of aggregate are pushed towards the sample centre. The walls of the forms enforce the change in orientation of bigger grains. As a result of impact compaction according to Marshall, a heterogeneous structure of the mixture is obtained, different on the surface of the sample from that inside of the sample.

Compacting with Marshall's compactor does not result in a proper orientation of aggregate structure, which is the case in practice. It should be also emphasised that the asphalt mixture as early as in the initial stage of formfilling, undergoes initial segregation. It should be added that segregation becomes more distinct when coarsegrained mixtures (DR-DM) undergo compaction. Impact compaction results in enveloping aggregate grains in a very thin mastics membrane and in many cases its disappearance altogether.

Summing up, it should be pointed out that the impact method apart from its merits, eg low service costs, convenience in its application, has also many drawbacks, above all: discontinuity of bituminous membrane, being the cause of the direct contact of exposed surfaces of aggregate grains, presence of numerous crushed and broken aggregate grains, heterogeneity of compacted mixture's structure.

Rolling-wheel compaction is free from many of the above-mentioned negative characteristics. Asphalt mixture is laid over a large area, so the influence of sidewalls on the compaction is minimal. The way the compacting tension works here is also different. Due to the use of vibrating compaction in the initial stage, "settling" of mixture follows - solid grains create a skeleton, fine fractions fill the air voids (the imitation of vibrating plate compaction of a spreader in conditions "in situ"). Then, due to the action of a combination of shearing and compressive stresses, under the steel roller there emerges a compact, oriented structure of asphalt. As a result of such compaction, the mastics membrane surrounding the aggregate grains is thicker in comparison with the impact compaction.

The samples drilled out of the plates and the samples cut out of the surface had similar pattern of large grains. Homogeneity of grain orientation and air voids could be observed nearly within the complete volume of samples. The samples prepared according to Marshall's method had far smaller homogeneity of air space distribution.

\section{The research on the strength properties of asphalt concrete}

The strength properties were defined as variables with the following denominations:

- stability (according to Marshall's method),

- flow (according to Marshall's method),

- stiffness index,

- resistance to tension acc to the Brazilian test at $10^{\circ} \mathrm{C}$,

- resistance to tension acc to the Brazilian test at $0{ }^{\circ} \mathrm{C}$,

- the volume of air voids in the compacted asphalt mixture,

- the speed of creep,

- permanent deformations tested at cyclic pressing at $0.1 \mathrm{MPa}$ stress amplitude (accumulated deformation),

- permanent deformations tested with cyclic pressing at $0.2 \mathrm{MPa}$ stress amplitude (accumulated deformation),

- complex module $\mathrm{G}^{*}$ (stress amplitude of $0.1 \mathrm{MPa}$ )

- storage module G' (stress amplitude of 0.1 MPa),

- phase shift $\Delta_{1}$ (stress amplitude of $0.1 \mathrm{MPa}$ ),

- phase shift $\Delta_{2}$ (stress amplitude of $0.2 \mathrm{MPa}$ ). 
The results of strength tests were subsequently analysed in the context of principal components. On the basis of eigenvalues, the significance of principal components was estimated. The first three components have been found significant, collectively explaining $95.75 \%$ of total variance variation.

Between the variables for the 3 compacting methods and 2 types of asphalt mixtures, corelation coefficients have been defined. The first principal component accounts for the largest value of research results variation. Its significance is established by stability, flow, stiffness index and permanent deformations accumulation, storage module and phase shift tangent. The physical quality of that component can be defined as material's deformation ability indicator. The second principal component $(22.83 \%$ of discussed variance variation), dominated by the variable of tensile resistance at $0{ }^{\circ} \mathrm{C}$ according to the Brazilian method, may be defined as the indicator of the resistance of the tested asphalt mixture to stretching in the elastic range. The third principal component characterises the asphalt mixture resistance to tensile in the viscoelastic range (tensile strength at $10^{\circ} \mathrm{C}$ according to Brazilian method).

Fig 1 shows the graphs of the first two principal components. On the basis of these graphs, the degree of interdependence existing between the applied methods of investigation, types of asphalt mixtures and the methods of compacting have been determined. This dependence has been called 'sensitivity' of asphalt mixture and the compacting method to the parameters determined by investigation methods. The points defining the mixture type and the method of compacting, located in the centre of the graph of principal components (the beginning of the coordinate system, Fig 1) have a medium sensitivity (S), the ones on the opposite side of the vector of investigation method parameter have a low sensitivity (M), the points - significant sensitivity (D). The sensitivity concrete are in Table 1.

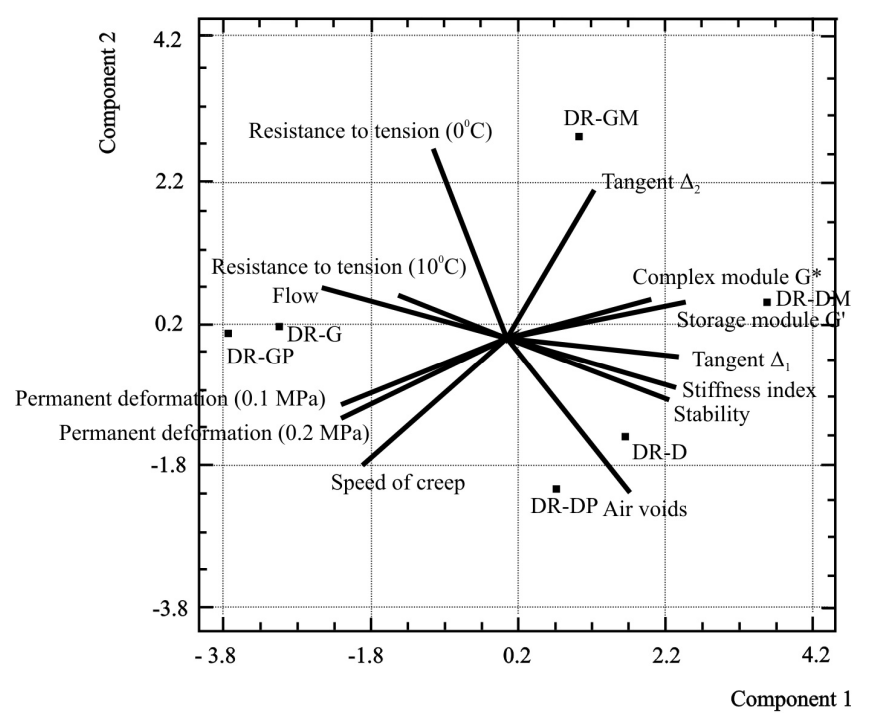

Fig 1. Graph of the principal components
Table 1. The sensitivity of asphalt concrete

\begin{tabular}{|c|c|c|c|c|c|c|}
\hline Variables & \begin{tabular}{l}
0 \\
\multirow{2}{*}{} \\
\end{tabular} & 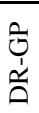 & $\begin{array}{l}\sum_{j} \\
\frac{1}{0}\end{array}$ & 莫 & & 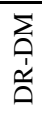 \\
\hline 1. Stability & $\mathrm{M}$ & $\bar{M}$ & $\dot{S}$ & $\dot{S}$ & $\dot{S}$ & $\dot{S}$ \\
\hline 2. Flow & $\mathrm{D}$ & D & Ś & Ś & Ś & Ś \\
\hline 3. Stiffness index & $\mathrm{M}$ & M & Ś & Ś & Ś & Ś \\
\hline $\begin{array}{l}\text { 4. Resistance to } \\
\text { tension }-10{ }^{\circ} \mathrm{C}\end{array}$ & Ś & Ś & Ś & Ś & Ś & $\dot{S}$ \\
\hline $\begin{array}{l}\text { 5. Resistance to } \\
\text { tension }-0^{\circ} \mathrm{C}\end{array}$ & Ś & Ś & D & M & M & Ś \\
\hline 6. Air voids & $\dot{S}$ & $\dot{S}$ & Ś & $\mathrm{D}$ & $\mathrm{D}$ & $\dot{S}$ \\
\hline 7. Speed of creep & Ś & Ś & Ś & Ś & Ś & Ś \\
\hline $\begin{array}{l}\text { 8. Permanent deforma- } \\
\text { tion - the amplitude } \\
\text { of stress } 0.1 \mathrm{MPa}\end{array}$ & Ś & Ś & M & Ś & Ś & M \\
\hline $\begin{array}{l}\text { 9. Permanent deforma- } \\
\text { tion - the amplitude } \\
\text { of stress } 0.2 \mathrm{MPa}\end{array}$ & Ś & Ś & Ś & Ś & Ś & M \\
\hline 10. Complex module $\mathrm{G}^{*}$ & M & M & Ś & $\dot{S}$ & Ś & $\mathrm{D}$ \\
\hline 11. Storage module G' & M & M & Ś & Ś & Ś & $\mathrm{D}$ \\
\hline 12. Tangent $\Delta_{1}$ & $\mathrm{M}$ & M & $\dot{S}$ & Ś & Ś & $\mathrm{E}$ \\
\hline 13. Tangent $\Delta_{2}$ & S & S & D & S & Ś & $\mathrm{E}$ \\
\hline
\end{tabular}

Table 1 indicates that asphalt mixtures, which had been compacted with a rolling wheel, have similar 'sensitivity' to that of the mixtures compacted on the road surface 'in situ'. Their location on the graph of the principal components (Fig 2) is very close. It is not so with the mixtures compacted by Marshall's method. On the graph of principal components, the mixtures are laid out in stripe-pattern according to the type, while the mixtures compacted by Marshall's method were apparently dispersed. Asphalt mixture compacted with this method shows big values of $\mathrm{G}^{*}$ and $\mathrm{G}^{\prime}$ modules and, according to their resistance to deformations, is increased in fatiguetesting, while the actual behaviour of mixtures 'in situ' is different. Summing up the compaction investigations and analyses it is possible to make the following conclusions:

- The samples compacted by Marshall's method feature various aggregate structures and varied content of void spaces in the areas near the walls of forms, in the upper and lower surfaces and internally.

- The presence of uncut aggregate grains of large sizes near the exterior surfaces of samples (Marshall's samples, plate edges) may have a negative effect on the investigated samples' strength in comparison with the samples drilled out of the road surface.

- Cutting (drilling) line located at least $5 \mathrm{~cm}$ off the plate's edge; $2 \mathrm{~cm}$ away from another sample and $1 \mathrm{~cm}$ off the sample's bottom (rolling-wheel method) define homogeneously compacted volumes of asphalt mixtures by plate-rolling method.

- The samples compacted by the rolling method exhibit the strength properties corresponding with those of the samples cut out of the road surface.

- Compacting asphalt mixtures in a laboratory to satisfy 'in situ' conditions ought to be performed with the rolling method. 


\subsection{Methods of testing asphalt mixtures resistance to permanent deformations}

Considering the test results presented in part 2.1, compaction of specimens for rutting tests was made by means of rolling. Specimens for dynamic creep tests were made in a gyratory press due to height requirements.

Laboratory tests on asphalt mixture specimens were conducted in 3 stages: non-aged samples, after short-term aging and after long-term ageing. Short-term ageing laboratory simulation involved heating up of non-compacted asphalt mixture in a $25-50 \mathrm{~mm}$ thick course for 2 hours at a temperature, at which the binder's viscosity equal $0.28 \mathrm{~Pa}$. Asphalt mixture long-term ageing was conducted according to SHRP recommendations, whereby compacted asphalt mixture specimens, having been technologically aged, were heated in an air-streamed chamber at $85^{\circ} \mathrm{C}$ for 5 days. Additionally, while heated the specimens were held in the air stream. For a long-term aging of porous mixture specimens a specially designed device was used; it consisted of the climatic chamber, compressor, mould with a head and the base to feed air. Using this method, the samples were heated at $85^{\circ} \mathrm{C}$ for 5 days, while a stream of air was passing through them. The specimens were in a steel mould, insulated with silicon seal in such a way that the air stream was aimed at the specimen and did not pass it by .

Rutting was tested at $60^{\circ} \mathrm{C}$ with the use of the small rutmeter (Wessex apparatus by BS 598 PT:110:1996 standard). The test result was the maximum rut depth denominated in $\mathrm{mm}$ and rutting coefficient defined as an increase in rut depth $(\mathrm{mm} / \mathrm{h})$. Dynamic creep was tested at $40{ }^{\circ} \mathrm{C}$ in ELE MATTA apparatus according to BS DD213:1993 recommendations. Specimens of the following size: diameter $-100 \mathrm{~mm}$, height $-100 \mathrm{~mm}$ were exposed to cyclic axial loads (pulse duration $2000 \mathrm{~ms}$, pulse interval $1000 \mathrm{~ms}$, number of load pulses 1800). Creep stiffness modulus (MPa) and cumulated deformation (\%) were determined in the test. Each mixture was tested by two parallel specimens.

\section{Evaluation of asphalt mixture resistance to rutting and creeping}

\subsection{Testing the non-aged asphalt mixtures}

Fig 2 shows the results of non-aged asphalt mixture tests for permanent deformations determined in the rutting (maximum rut depth $\mathrm{R}_{\mathrm{d}}$, rutting coefficient RTS) and creep (dynamic creep stiffness modulus $\mathrm{E}_{\mathrm{P}}$, cumulated deformation $\varepsilon_{\mathrm{P}}$ ) tests.

The data in Fig 2 show that asphalt concretes with binders modified with fine rubber ( $21 \%$ of the modifier) and EVA plastomer (5\% of the modifier) are characterised by very favourable $R_{d}$ i RTS parameters (much lower values than those of asphalt concretes with unmodified binders). Very good results were also obtained for porous asphalt mixtures and especially for SMA with unmodified binder. The biggest stiffness module and the smallest values of cumulated deformations in the dynamic rut test and consequently the highest resistance to permanent deformation were obtained for Superpave mixture.
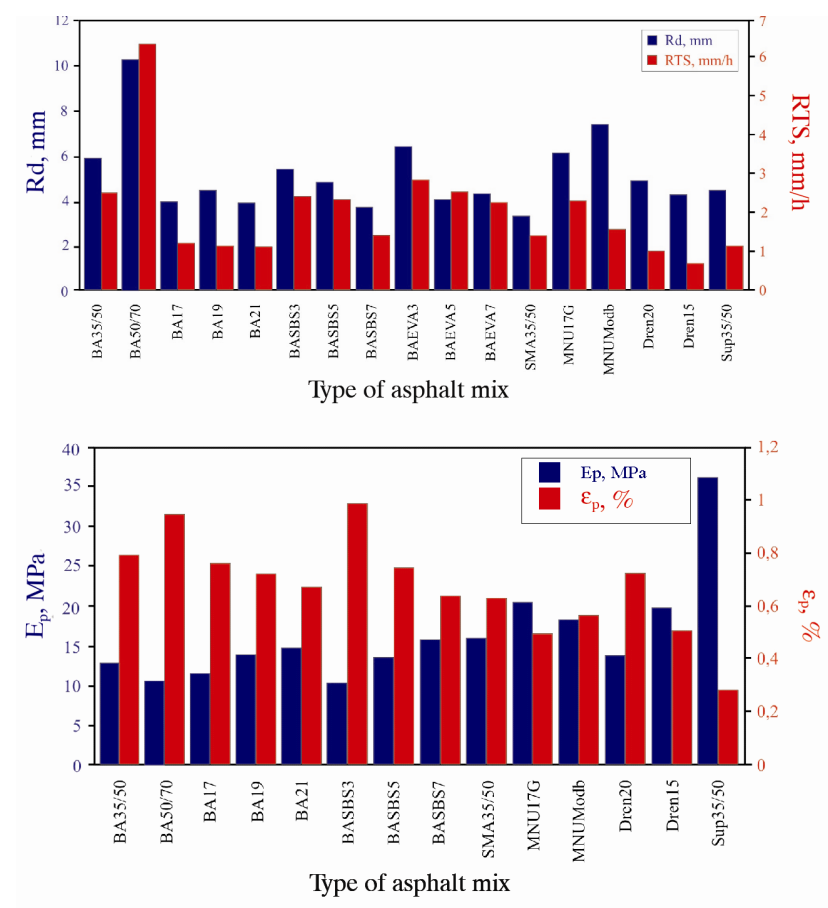

Fig 2. The results of rutting and creep tests of asphalt mixture specimens not exposed to laboratory aging

In view of the results shown in Fig 1 the tested mixtures can be classified in terms of their resistance to rutting and creeping. Weight system was applied. A weight of 1 was assigned to each parameter under evaluation. The asphalt mixtures characterised by the most favourable parameter values scored 1 point, the second best -2 points etc. If there were not any statistically significant differences between mean values of particular mixtures within the tested parameter, the binders formed a uniform group of a definite, identical grading level. The mixtures with the smallest number of points were assumed to be the most resistant to permanent deformations. The classification developed in the above way is as follows:

- Superpave mixture,

- porous asphalt mixture with a $15 \%$ of air voids,

- SMA with 35/50 binder,

- asphalt concrete with $21 \%$ of rubber modified binder, asphalt concrete with $7 \%$ of elastomer modified binder, asphalt concrete with $5 \%$ of plastomer modified binder,

- MNU with $17 \%$ of rubber modified binder, asphalt concrete with $19 \%$ of rubber modified binder, porous asphalt mixture with a $20 \%$ of air voids,

- asphalt concrete with $17 \%$ of rubber modified binder, MNU with Modbit 30B binder, asphalt concrete with $7 \%$ of plastomer modified binder,

- asphalt concrete with $5 \%$ of elastomer modified binder,

- asphalt concrete with $35 / 50$ bitumen,

- asphalt concrete with $3 \%$ of elastomer modified binder,

- asphalt concrete with $3 \%$ of plastomer modified binder,

- asphalt concrete with 50/70 bitumen. 


\subsection{Evaluation of asphalt mixture resistance to rut- ting and creeping after short-term ageing}

Fig 3 shows the test results of asphalt mixture rutting and creeping after they were exposed to short term ageing. In view of the results (Fig 3), the following mixtures stand out in terms of their resistance to rutting and creeping: SMA mixture, asphalt concretes with fine rubber (21\% of modifier), EVA plastomer ( $7 \%$ of modifier) modified binders, porous asphalt mixture with a $15 \%$ content of air voids and Superpave mixture. Elastomer modified mixture has stiffened less when exposed to short-term ageing; that is why its rutting results were slightly worse than the best ones. As far as creeping results are concerned, the following mixtures have the best properties: Superpave mixture, asphalt concrete with SBS elastomer modified binder ( $5 \%$ of modifier), MNU (with rubberised bitumen).
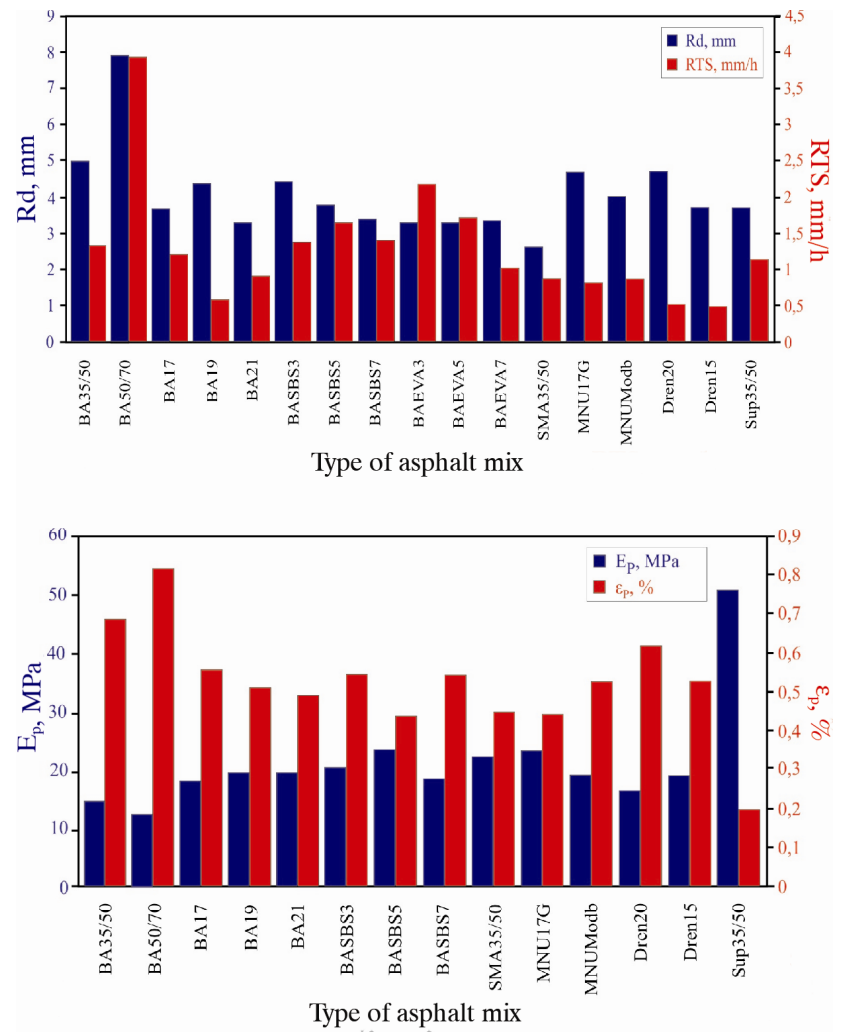

Fig 3. Test results of asphalt mixture rutting and creeping after they were exposed to short-term ageing

Technologically aged asphalt mixtures of best resistance to permanent deformations were selected. As in the case of non-aged mixtures, a weight system was adopted. The classification of the tested asphalt mixtures is as follows:

- SMA with 35/50 binder, Superpave,

- asphalt concrete with $21 \%$ of rubber modified binder, MNU with $17 \%$ rubber modified binder,

- asphalt concrete with $7 \%$ of plastomer modified binder, porous asphalt mixture with a $15 \%$ content of air voids,
- asphalt concrete with $19 \%$ of rubber modified binder, asphalt concrete with $5 \%$ elastomer modified binder,

- asphalt concrete with $7 \%$ of elastomer modified binder,

- MNU with Modbit 30B binder,

- asphalt concrete with $5 \%$ of plastomer modified binder,

- asphalt concrete with $3 \%$ of plastomer modified binder,

- asphalt concrete with $17 \%$ of rubber modified binder, porous asphalt mixture with a $20 \%$ content of air voids,

- asphalt concrete with $3 \%$ of elastomer modified binder,

- asphalt concrete with 35/50 bitumen,

- asphalt concrete with 50/70 bitumen.

\subsection{Evaluation of asphalt mixture resistance to rut- ting and creeping after long-term ageing}

The test results of asphalt mixture rutting and creeping after they were exposed to short-term ageing and long-term ageing are in Fig 4.
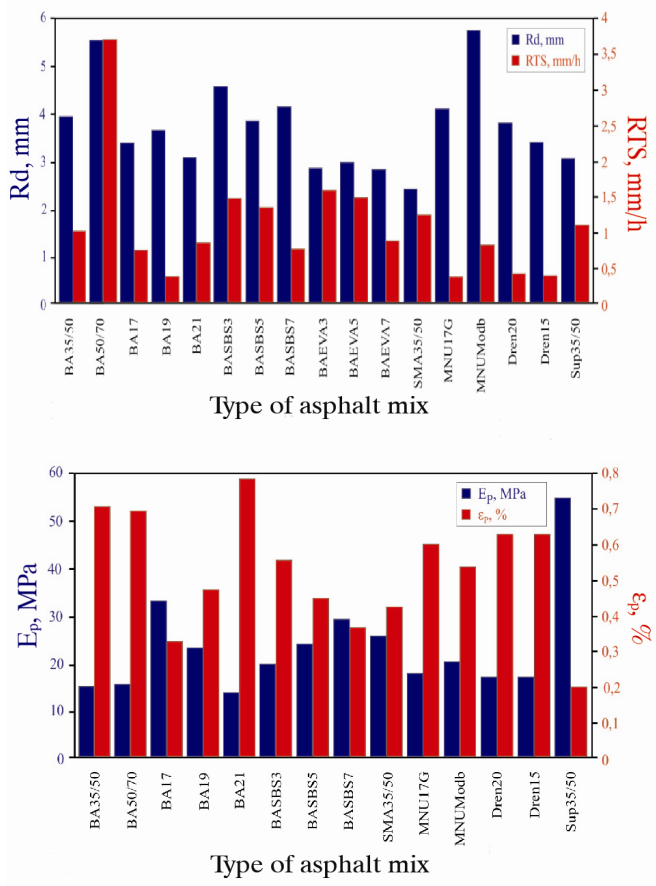

Fig 4. Test results of asphalt mixture rutting and creeping after they were exposed to short-term ageing and longterm ageing

The results in Fig 4 show that after laboratory longterm ageing asphalt concretes with plastomer modified bitumen, SMA mixture and Superpave mixture appeared to be the most resistant to rutting. Elastomer and fine rubber modified asphalt concretes exposed to ageing did not stiffen like other mixtures; on the contrary they became slightly more elastic and that is why their rutting results were considerably worse than those of the best 
ones although better than those of the asphalt concrete with unmodified binders. The best rut test results were those of Superpave mixture, asphalt concrete with SBS elastomer modified binder ( $7 \%$ of modifier), and asphalt concrete with rubberised bitumen containing $17 \%$ of rubber additive.

Then service-aged asphalt mixtures were classified according to their resistance to permanent deformations:

- asphalt concrete with $17 \%$ of rubber modified binder, SMA with 35/50 binders, Superpave;

- asphalt concrete with $19 \%$ of rubber modified binder, asphalt concrete with $7 \%$ of plastomer modified binder, asphalt concrete with $7 \%$ of elastomer modified binder;

- porous asphalt mixture with a $15 \%$ content air voids;

- asphalt concrete with $5 \%$ of plastomer modified binder, MNU with $17 \%$ of rubber modified, porous asphalt mixture with $20 \%$ content of air voids;

- asphalt concrete with $5 \%$ of plastomer modified binder, MNU with Modbit 30B binder;

- asphalt concrete with $21 \%$ of rubber modified binder, asphalt concrete with $3 \%$ of plastomer modified binder;

- asphalt concrete with $3 \%$ of elastomer modified binder, asphalt concrete with $35 / 50$ bitumens;

- asphalt concrete with 50/70 bitumen.

\subsection{Summary of asphalt mixture classification}

Asphalt mixtures tested in simulated technological and service processes do not all behave in the same way. Ageing causes stiffness to a greater extent in case of mixtures with unmodified binders than in case of mixtures with elastomer or rubberised bitumen binders. Special attention should be paid to Superpave mixture which contained unmodified binder. In terms of its permanent deformation evaluation it appeared to be most resistant both before and after short-term ageing and long-term ageing. So did SMA. It shows how the type of mixture, whose structure is based on a strong grit skeleton filled with a big amount of mastix which surrounds particular grains of aggregate with a tight and relatively thick coat, greatly influences its resistance.

The test results show that asphalt mixtures with rubberised bitumen binders are characterised by high resistance to permanent deformations. Rubberised bitumen binder properties depend on the process of rubber devulcanisation. Polymers which fine rubber contents do not dissolve well in hot bitumen when binder is being made. Rubber particles partially act as a filler which makes the mixture more flexible. When the content of fine rubber additive is high, the partially dissolved rubber particles form an elastic bond within the binder, which improves its mechanical properties. The fluorescent microscope tests confirm that rubberised bitumen binder is not fully homogenous. Particles of swollen, partially dissolved rubber can be seen. As a result of short-term ageing, the particles of swollen rubber are exposed to further heat treatment. The bitumen penetrates the rubber particles and swelling increases, which results in the binder stiffness diminishing. That is why, after a long-term ageing asphalt concrete with the highest content $(21 \%)$ of fine rubber in bitumen is less resistant to deformations than it was before and after short-term ageing.

The test results of asphalt concrete with polymer modified binders ( $7 \%$ addition) show that their resistance to permanent deformations is very good, especially after long-term ageing. As a result of ageing, a partial, thermal destruction of polymer occurs which affects binder stiffness diminishing. At the same time, polymer acting as an inhibitor of bitumen oxidation reduces oxidation; that is why ageing becomes slower. With a higher polymer content $(7 \%)$, bitumen stiffening due to modification is bigger than with a lower polymer content. That is why asphalt concrete with $7 \%$ polymer modified binder appears to be the most resistant to permanent deformations.

Porous asphalt mixture, due to its internal structure, is characterised by a high resistance to permanent deformations. As a result of ageing, they become stiffer, which increases their resistance to rutting and creeping. With such mixes, the intensity of long-term ageing depends on the content of air voids in a course and the kind and contents of asphalt binder.

\section{Evaluation method of modified binder asphalt mix- ture permanent deformation tests}

Rheological test results describing asphalt mixture properties in terms of their resistance to permanent deformations were evaluated according to the principal components analysis in the following groups:

I - parameters of stability, deformation and elastic stiffness modulus determined before ageing obtained by means of Marshall's apparatus,

II - after short-term ageing,

III - after short-term ageing and long-term ageing,

IV - all parameters accounted for together.

The strength of correlation between the parameters used to define rutting and creep resistance was determined and parameters best characterising the tested mixtures properties before and after short-term ageing and after short-term ageing and long-term ageing were selected. The following sets of parameters were obtained:

I - rutting coefficient and cumulated deformation in the creep test, properties of mixtures unexposed to ageing,

II - rut maximum depth and cumulated deformation in the creep test, properties of mixtures after short-term ageing,

III - rut maximum depth, creep stiffness modulus and cumulated deformation in the creep test, properties of mixtures in after short-term ageing and long-term ageing,

IV - rut maximum depth after short-term ageing, rutting coefficient after operational ageing, creep stiffness modulus after long-term ageing and cumulated deformation after short-term ageing.

Fig 5 shows results of the principal components analysis referring to selected parameters of group IV 
which, due to coefficient values of corelation with the principal components and corelations among one another, were chosen for describing asphalt mixtures resistance to permanent deformations.

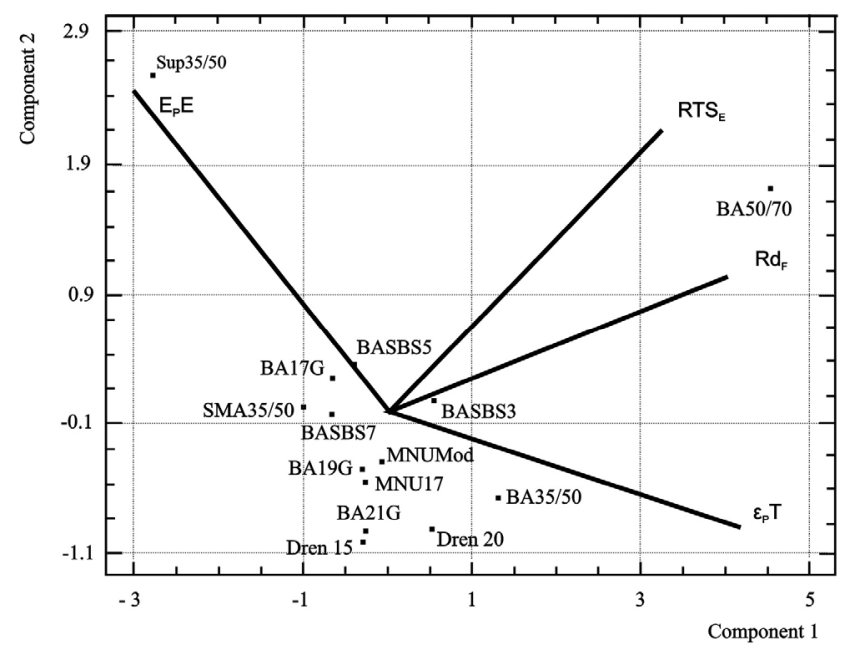

Fig 5. Principal components - lay-out of parameters selected for evaluating the modified asphalt mixtures resistance to permanent deformations

While analysing 'sensitivity', ie the strength of interdependence between the type of modified asphalt mixture and parameters selected for evaluating the resistance to permanent deformation, it should be stated here that Superpave mixtures are characterised by a high 'sensitivity' due to dynamic creep stiffness modulus. Asphalt concrete with 50/70 binder is the most 'sensitive' in the rut test. Porous asphalt mixture, asphalt concrete with $35 / 50$ bitumen and asphalt concrete with a high content of fine rubber can be characterised as 'sensitive' to the selected parameters. The other mixtures can be classified as medium 'sensitive', which means that all the selected parameters characterise them equally well in terms of their resistance to permanent deformations.

The principal components analysis shows that rut and creep tests of technologically and service aged asphalt mixtures provide the fullest evaluation of resistance to permanent deformations. Simultaneous determination of 4 parameters makes it possible to fully characterise asphalt mixtures designed to be built in the wearing course of a road pavement.

\section{Conclusions}

The results of the research and analysis lead to the following conclusions:

- Laboratory compaction of asphalt mixtures to satisfy 'in situ' conditions ought to be conducted by means of the rolling compaction method.

- While being exposed to simulated short-term ageing and long-term ageing, asphalt mixtures behave differently in terms of rutting and creeping. Ageing causes more stiffness with unmodified binder mixtures than with polymer or rubberised bitumen modified binder mixtures.
- Resistance to permanent deformations depends on the type of asphalt mixture and the type of binder used. Asphalt concrete with rubberised bitumen, asphalt concrete with $7 \%$ polymer modified binders and SMA and Superpave mixtures with unmodified binders appeared to be most resistant to permanent deformations after long-term laboratory ageing.

The fullest evaluation of resistance to permanent deformations can be obtained by testing asphalt mixtures rutting and creeping while they are being technologically and service aged. Simultaneous determination of 4 parameters: rut maximum depth after short-term ageing, rut coefficient after long-term ageing, creep stiffness modulus after long-term ageing and cumulated deformation after short-term ageing makes it possible to fully characterise modified asphalt mixtures designed to be built in the wearing course of a road pavement.

\section{References}

1. GEZENCVEJ, L. B. Asphalt concrete for roads surfaces. Moscow: Transport, 1985. 343 p. (in Russian).

2. KANDHAL, P. S.; COOLEY, L. A. Evaluation of permanent deformation of asphalt mixtures using loaded wheel tester. National Center for Asphalt Technology, Auburn University, Annual Meeting of The Association of Asphalt Paving Technologists, Auburn, 2002, p. 1-12.

3. PIŁAT, J.; RADZISZEWSKI, P. Asphalt pavements. Warsaw: Transport and Telecommunications Publishing, 2004. 517 p. (in Polish).

4. RADZISZEWSKI, P.; KALABIŃSKA, M.; PIŁAT, J. Road materials and asphalt pavements. Publishing Department of the Technical University. Białystok and Publishing House of Warsaw University of Technology. Białystok-Warsaw, 1995. 348 p. (in Polish).

5. GAWEŁ, I.; KALABIŃSKA, M.; PIŁAT, J. Road asphalts. Warsaw: Transport and Telecommunications Publishing, 2001. 292 p. (in Polish).

6. ZHANG, J.; COOLEY, L. A.; KANDHAL, P. S. Comparison of fundamental and simulative test methods for evaluating permanent deformation of hot mix asphalt. $\mathrm{Na}$ tional Center for Asphalt Technology Report 02-07, Auburn, 2002, p. 1-16.

7. NEUBAUER, O.; PARTL, M. N. Impact of binder content on selected properties of stone mastic asphalt. In 3-rd Eurasphalt \& Eurobitume Congress, Vienna, 2004, p. 1614-1621.

8. BONNOT, J. French experience on porous asphalt. In Proc of the European Conference on Porous Asphalt, Madrid, 1997, p. 1173.

9. BOWSKILL, G. J.; COLWILL, D. M. Experience with porous asphalt in the United Kingdom. In European Conference on Porous Asphalt, Madrid, 1997, p. 1091-1127.

10. BHASIN, A.; BUTTON, J. W.; CHOWDHURY, A. Evaluation of simple performance tests on hot-mix asphalt mixture from south Central United States. Transportation Research Record, Vol 1891, Transportation Research Board of the National Academies, USA, 2004, p. 174181.

11. ABDELRAHMAN, M. Controlling performance of crumb rubber-modified binders through addition of polimer modifiers. Transportation Research Record, 
Vol 1962, Transportation Research Board of the National Academies, USA, 2006, p. 64-70.

12. DUMONT, A. G.; OULD-HENIA, M. Effect of modified binder on cracking resistance of pavements. In Proc of the Fifth International Rilem Conference, Limoges, France, 2004, p. 511-518.

13. JUDYCKI, J. Road asphalts and elastomer modified asphalt mixtures. Scientific Papers of Gdansk Technical University, No 452, Gdańsk, 1991. 254 p. (in Polish).

14. RADZISZEWSKI, P.; KALABIŃSKA, M.; PIŁAT, J. Comparative analysis of bitumen-rubber binder and polish standard bitumen properties. In Proc of the Asphalt Rubber 2003 Conference, Brazil, 2003, p. 337 - 345.

15. AL-KHATEEB, G.; XICHENG, QI.; SHENOY, A.; STUART, K.; MITCHELL, T. Assessment of aging at FHWA's pavement testing facility. Transportation Research Record, Vol 1940, Transportation Research Board of the National Academies, USA, 2005, p. 146-155.

16. AR-RABTI, A. H. The effect of aging on mechanical properties of asphalt concrete, stone mastic asphalt and porous asphalt mixes. Doctor's thesis, Technical University of Gdańsk, Gdańsk, 1998. 229 p.
17. RADZISZEWSKI, P.; PIŁAT, J.; ZIÓŁKOWSKI, R. Short term and long term aging influence on modified bitumens resistance to low temperature cracking and fatigue cracking. In Proc of the Fifth International Rilem Conference, Limoges, France, 2004, p. $501-510$.

18. SAFWAT, F. SAID. Aging effect on mechanical characteristics of bituminous mixtures. Transportation Research Record, Vol 1901, Transportation Research Board of the National Academies, USA, 2005, p. 146-155.

19. SHALABY, A. Modeling short-term aging of asphalt binder using the rolling thin film oven test. Can J. Civ. Eng., 2002, Vol 29, p. 135-144.

20. HARVEY, J. T. Mix design compaction procedures for hot mix asphalt concrete and rubber - modified asphalt concrete mixtures. Berkeley: University of California, 1992. $450 \mathrm{p}$.

21. RADZISZEWSKI, P. Mineral-asphalt composites' fatigue life modelling. Scientific Thesis No 45, Publishing Dept of the Technical University in Białystok, Białystok, 1997. 185 p. (in Polish).

22. GREŃ, J. Mathematical statistics. Models and problems. Warsaw: PWN, 1984. 362 p. (in Polish).

\section{MODIFIKUOTŲ ASFALTO MIŠINIŲ ATSPARUMAS LIEKAMOSIOMS DEFORMACIJOMS}

\section{P. Radziszewski}

\section{S antrauka}

Provėžas paliekančios liekamosios deformacijos yra viena iš dažniausių pažaidų, bloginančių eksploatacines kelio dangos savybes. Naudojant tam tikrą asfalto mišinio ir rišiklio modifikacija, efektyviai galima gerinti asfalto savybes. Gamybos, tiekimo, klojimo bei ilgalaikès eksploatacijos metu bituminiuose rišikliuose bei asfalto mišiniuose nenutrūkstamai vyksta neigiami senejjimo procesai, kurie lemia esminga savybių, tarp ju ir atsparumo liekamosioms deformacijoms, kaita. Straipsnyje pateikiami betono, SMA (skaldos, mastikos, asfaltbetonio), MNU (plonų nevientisos struktūros sluoksniu), Superpave (aukštos kokybės asfaltbetonio) mišinių ir $15 \%$ bei $20 \%$ tuštumingumo poringojo asfalto provèžų ir dinaminiai valkšnumo tyrimų rezultatai. Asfaltbetonio, MNU ir poringojo asfalto mišiniai buvo su elastomeriniais, plastomeriniais bei smulkios gumos modifikuotais rišikliais. Bandiniai laboratoriniams provėžų bandymams buvo gaminami sutankinant asfalto plokštes, nes, kaip parodè ankstesni autoriaus tyrimai, šis metodas labiausiai atitinka realias klojimo sąlygas. Atsparumo liekamosioms deformacijoms tyrimai atlikti prieš senėjima, po technologinio (trumpalaikio) senejjimo bei eksploatacinio (ilgalaikio) senėjimo. Bandymu rezultatai parodè, kad atsparumas liekamosioms deformacijoms priklauso nuo asfalto mišinio ir rišiklio. Nustatyta, kad asfaltbetonio mišiniai, turintys smulkios gumos bitumų, asfaltbetonio mišiniai, turintys 7 \% polimerais modifikuotų rišiklių, SMA bei Superpave mišiniai, turintys nemodifikuotų rišiklių, po ilgalaikio senejjimo laboratorijos sąlygomis yra atspariausi liekamosioms deformacijoms. Irodyta, kad bendras atsparumo liekamosioms deformacijoms vertinimas gali būti atliktas, taikant trumpalaikio bei ilgalaikio senèjimo veikiamu asfalto mišinių provėžų ir valkšnumo bandymus. Vienu metu apskaičiuojami 4 parametrai - maksimalus provėžų gylis po trumpalaikio senèjimo, provėžų koeficientas po klojimo senėjimo, valkšnumo modulis po ilgalaikio senèjimo ir suminès deformacijos po trumpalaikio senèjimo - palengvina nustatyti modifikuotu, kelio dangoms skirtų asfalto mišinių sudèti.

Reikšminiai žodžiai: modifikuotasis asfalto mišinys, tankinimas, senejimas, liekamosios deformacijos, provėža, valkšnumas.

Piotr RADZISZEWSKI. Vice-Rector for Promotion and Cooperation at the Bialystok Technical University, Professor at the Faculty of Civil and Environmental Engineering. His research interests include highway engineering in topics such as reological properties of modified bitumens, fatigue and permanent deformation, ageing asphalt mixes. 